\title{
PENGARUH KEGIATAN EKSTRAKURIKULER DAKWAH ROHIS TERHADAP SEMANGAT BERIBADAH SISWA DI SMPN 28 TANGERANG
}

\author{
Nur Afif*, Okky Setiawan Sahid** \\ *nurafif @ ptiq.ac.id ***okkysetiawann44@gmail.com \\ *Dosen Fakultas Tarbiyah Institut PTIQ Jakarta \\ ***Mahasiswa Fakultas Tarbiyah Institut PTIQ Jakarta
}

\begin{abstract}
Tujuan dalam penelitian ini adalah (1) Untuk mengetahui nilai-nilai dakwah pada kegiatan ekstrakurikuler Rohis di SMPN 28 Tangerang. (2) Untuk mengetahui semangat beribadah siswa setelah ada kegiatan ekstrakurikuler dakwah Rohis. Berdasarkan hasil uji t terlihat dari hasil olah data SPSS 25.00 yaitu nilai constanta sebesar 0,368 dengan hasil uji t mempunyai tingkat signifikansi 2,666 $(\alpha>0,05)$ berarti secara parsial terdapat pengaruh yang signifikan dan searah antara Variabel X (Kegiatan Ekstrakurikuler Dakwah Rohis) terhadap Variabel Y (Semangat Beribadah Siswa) di SMPN 28 Tangerang. Maksud terdapat pengaruh yang signifikan dan searah adalah semakin baik kegiatan ekstrakurikuler dakwah rohis maka semakin meningkat pula semangat beribadah yang dimiliki siswa di SMPN 28 Tangerang, jika semakin buruk kegiatan ekstrakurikuler dakwah rohis akan menghambat semangat beribadah siswa di SMPN 28 Tangerang.
\end{abstract}

Keywords: Kegiatan Ekstrakulikuler, Dakwah Rohis, Semangat Beribadah Siswa 


\section{A. PENDAHULUAN}

Pendidikan formal di sekolah terdiri atas intrakurikuler dan ekstrakurikuler. Kegiatan atau aktivitas ekstrakurikuler adalah kegiatan yang dilakukan siswa di luar jam mata pelajaran. Berbagai macam kegiatan ekstrakurikuler di sekolah terdiri atas pramuka, Palang Merah Remaja (PMR), Patroli Keamanan Sekolah (PKS), Jurnalistik, Seni, Olahraga, dan juga Rohani Islam (Rohis). Rohis ini merupakan sebuah ekstrakurikuler yang berbasis keagamaan (Muhammad Alim, 2011.

Kegiatan pendidikan tidak hanya belajar di kelas tetapi ada yang di luar kelas yaitu ekstrakurikuler. "Kegiatan ekstrakurikuler merupakan beberapa kegiatan yang diberikan kepada peserta didik di lembaga pendidikan yang bertujuan untuk menonjolkan potensi diri yang belum terlihat di luar kegiatan belajar mengajar, memperkuat potensi yang telah dimiliki peserta didik" (Eka Prihtin, 2011)

Kegiatan ekstrakurikuler dakwah Rohis terbagi menjadi dua yaitu dakwah ammah (umum) dan dakwah khashah (khusus) (Depag RI, 2004). Pada penelitian ini lebih fokus pada dakwah ammah (umum) yaitu meliputi: (1) Penyambutan siswa baru, Program ini mengenalkan siswa baru dengan berbagai kegiatan dakwah sekolah, pengurus dan alumninya (2) Penyuluhan problem remaja, Program penyuluhan problematika remaja sangat menarik minat para siswa karena permasalahannya (Koesmarwanti dan Nugroho Widayantoro, 2000)

Tujuan Rohis secara umum yang di laksanakan disekolah khususnya di sekolah menengah pertama (SMP) dan sekolah menengah atas (SMA) adalah untuk mewujudkan barisan remaja pelajar yang mendukung dan memelopori tegaknya nilai-nilai kebenaran, mampu menghadap tantangan masa depan dan menjadi batu bata yang baik dalam bangunan masyarakat Islami (Nugroho Widiyantoro, 2003)

Ekstrakurikuler Rohis yang ada disekolah tersebut memiliki berbagai kegiatan yang sangat mendukung dalam perkembangan sikap religius siswa, seperti kajian-kajian keislaman yang menjadi program mingguan, kajian kelas yang menuntut siswanya aktif berpartisipasi, kegiatan mentoring, tahfidz, (Depag RI, 2004) dan berbagai program lainnya yang menjadi icon dalam pelaksanaan program dalam ekstrakurikuler tersebut. Sebagaian besar kegiatan yang ada, siswa sangat berperan dalam pelaksanaannya, selain adanya dukungan dari guru-guru yang mengampu ekstrakurikuler itu (AdzDzaky, Hamdani Bakran, 2002). Namun yang menjadi problematika disini adalah rendahnya minat siswa dalam mengikuti kegiatan-kegiatan yang dilaksanakan didalam ekstrakurikuler tersebut.

Ekstrakurikuler Rohis di SMPN 28 Tangerang memiliki sesuatu hal yang lebih mengutamakan dakwah Islam secara damai, menjaga ukhuwah Islamiyah dengan kuat dan toleransi antar umat beragama. Kemudian Rohis SMPN 28 Tangerang juga memiliki peran penting dalam bidang keagamaan Islam yang dapat mewadahi siswa dalam mengembangkan pengetahuan atau pemahaman siswa mengenai agama Islam, agar hasil belajar siswa terutama pada pelajaran agama Islam lebih baik, akan tetapi siswa hanya sedikit yang berminat menjadi pengurus dan anggota Rohis di sekolah.

Kemudian masih banyak siswa yang belum mengimplementasikan hasil belajar pendidikan agama Islam dalam kehidupan sehari-hari, hal tersebut terlihat dari sikap siswa yang masih belum sesuai dengan apa yang di pelajari pada saat pelajaran pendidikan agama Islam.

Seperti sekolah menengah yang lain pada umumnya, memiliki ekstrakurikuler Rohis sebagai wadah pembinaan untuk siswa dalam bidang agama Islam, namun di SMPN 28 Tangerang merupakan sekolah umum, dengan mayoritas siswasiswinya beragama Islam, akan tetapi minat atau antusias siswa lebih pada pelajaran umum bukan pada pelajaran agama Islam, hal tersebut berdasarkan kondisi yang ada di sekolah yang lebih mengutamakan pelajaran umum. 
Dari berbagai permasalahan yang ada, untuk itu peneliti ingin membahas tentang ekstrakurikuler Rohani Islam di SMPN 28 Tangerang.

\section{B. METODE PENELITIAN}

Tempat penelitian adalah tempat dimana penelitian akan dilakukan, penelitian ini dilakukan di SMPN 28 Tangerang yang bertempat Kelurahan Paninggilan Utara, Kecamatan Ciledug, Kota Tangerang.

Penelitian ini menggunakan metode kuantitatif yang dapat diartikan sebagai prosedur penulisan yang menghasilkan data-data deskriptif. Tujuan analisis kuantitatif adalah untuk mengetahui seberapa besar pengaruh suatu variabel atau hal terdapat variabel lain secara kuantitatif Analisis ini menggunakan suatu perhitungan melalui metode statistik dan untuk mempermudah analisis data maka dalam penelitian ini menggunakan teknik Quantity Function Deployment SPSS versi 25.00 .

Populasi dalam penelitian ini adalah sebagian siswa kelas VIII dan IX yang mengikuti Kegiatan Ekstrakurikuler Dakwah Rohis di SMPN 28 Tangerang. Adapun jumlah dari siswa tersebut berjumlah 40 siswa, yang terdiri dari 20 siswa laki-laki dan 20 siswa perempuan.

Teknik pengumpulan data yang digunakan dalam penelitian ini yaitu angket (angket tertutup dengan 5 skala Likert), observasi, wawancara dan dokumentasi. Uji keandalan data menggunakan uji validitas dan uji reliabiltas data dengan bantuan progam software program SPSS versi 25.00

Teknik analisis data dalam penelitian ini adalah analisis deskriptif analisis regresi linier, koefisien determinasi berganda dan uji asumsi klasik. Analisis regresi linier menggunakan metode statistika yang didukung perangkat lunak yaitu menggunakan program SPSS versi 25.00

\section{HASIL DAN PEMBAHASAN Hasil Uji Koefisien Determinasi $\mathbf{R}^{2}$}

Koefisian Determinasi $\left(\mathrm{R}^{2}\right)$ pada intinya mengukur seberapa jauh kemampuan model dalam menerangkan variabel-variabel dependen. Nilai koefisian determinasi adalah antara nol sampai dan satu. Nilai determinasi ditentukan dengan nilai Adjusted $\mathrm{R}$ Square. Hasil pengujian koefisian determinasi $\mathrm{R}^{2}$ dapat dilihat pada Tabel 1 berikut ini :

Tabel 1 Uji Koefisien Determinasi $\left(\mathbf{R}^{\mathbf{2}}\right)$

\begin{tabular}{|l|c|c|c|c|c|}
\hline \multicolumn{7}{|c|}{ Model Summary } \\
\hline Model & $\mathbf{R}$ & $\begin{array}{c}\mathbf{R} \\
\text { Square }\end{array}$ & $\begin{array}{c}\text { Adjusted } \\
\text { R Square }\end{array}$ & $\begin{array}{c}\text { Std. Error } \\
\text { of the } \\
\text { Estimate }\end{array}$ & $\begin{array}{c}\text { Durbin- } \\
\text { Watson }\end{array}$ \\
\hline 1 &, $397^{\text {a }}$ &, 158 &, 135 & 3,479 & 1,755 \\
\hline $\begin{array}{l}\text { a. Predictors: } \\
\text { Ekstrakurikuler }\end{array}$ \\
\hline \multicolumn{4}{|l|}{ (Constant), Kegiatan } \\
b. Dependent Variable: Semangat beribadah \\
\hline
\end{tabular}

Dari output di atas, terlihat nilai adjust $\mathrm{R}$ square atau pengaruh simultan variabel Kegiatan Ekstrakurikuler Dakwah Rohis (X), sebesar 0,158. Sehingga dapat disimpulkan bahwa pengaruh Kegiatan Ekstrakurikuler Dakwah Rohis, juga turut mempengaruhi Semangat Beribadah Siswa adalah sebesar 0,397 (39,7\%).

\section{Hasil Uji F}

Hasil pengujian statistik $F$ dapat dilihat pada Tabel 2 berikut ini.

Tabel 2 Hasil Uji F

\begin{tabular}{|l|l|c|c|c|c|c|}
\hline \multicolumn{7}{|c|}{ ANOVA } \\
\hline \multicolumn{2}{|c|}{ Model } & $\begin{array}{c}\text { Sum of } \\
\text { Squares }\end{array}$ & $\begin{array}{c}\text { Mean } \\
\text { Dquare }\end{array}$ & F & Sig. \\
\hline \multirow{2}{*}{1} & Regression & 86,017 & 1 & 86,017 & 7,108 &, $011^{\text {b }}$ \\
\cline { 2 - 7 } & Residual & 459,883 & 38 & 12,102 & & \\
\cline { 2 - 7 } & Total & 545,900 & 39 & & & \\
\hline
\end{tabular}

Berdasarkan Tabel 2 Terlihat nilai $\mathrm{F}$ hitung 7,108 dengan probabilitas > 3.245 , itu berarti nilai probabilitas $<0,05$, sedangkan hasil yang diperoleh dari $\mathrm{F}$ tabel adalah sebesar 4,01 yang berarti $F$ hitung $>$ F tabel $(7,108>3.245)$, sehingga model regresi dapat digunakan untuk memprediksi Kegiatan Ekstrakurikuler Dakwah Rohis (X), berpengaruh terhadap Semangat Beribadah Siswa (Y) pada SMPN 28 Tangerang atau model sudah tepat. 


\section{Hasil Uji Hipotesis (Uji Statistik t)}

Uji statistik $t$ pada dasarnya menunjukkan seberapa jauh pengaruh satu variabel penjelas/ independen secara individual dalam menerangkan variasi variabel dependen. Pada uji t, nilai t hitung akan dibandingkan dengan nilai $\mathrm{t}$ tabel. Berikut hasil perhitungan uji statistik $t$ yang disajikan pada Tabel 4 sebagai berikut:

Tabel 3 Hasil Uji t

\begin{tabular}{|c|c|c|c|c|c|c|}
\hline \multicolumn{7}{|c|}{ Coefficients $^{\mathrm{a}}$} \\
\hline & \multirow[t]{2}{*}{ Model } & \multicolumn{2}{|c|}{$\begin{array}{c}\text { Unstandardiz } \\
\text { ed } \\
\text { Coefficients }\end{array}$} & \multirow{2}{*}{$\begin{array}{c}\begin{array}{c}\text { Standardiz } \\
\text { ed } \\
\text { Coefficients }\end{array} \\
\text { Beta } \\
\end{array}$} & \multirow[t]{2}{*}{$\mathbf{T}$} & \multirow{2}{*}{$\begin{array}{c}\text { Sig } \\
\text { • }\end{array}$} \\
\hline & & B & $\begin{array}{c}\text { Std. } \\
\text { Error }\end{array}$ & & & \\
\hline \multirow[t]{2}{*}{1} & (Constant) & $\begin{array}{c}34,64 \\
0\end{array}$ & 7,451 & & $\begin{array}{c}4,64 \\
9\end{array}$ & $\begin{array}{c}, 00 \\
0\end{array}$ \\
\hline & $\begin{array}{l}\text { Kegiatan } \\
\text { Ekstrakurikul } \\
\text { er }\end{array}$ & ,368 &, 138 & ,397 & $\begin{array}{c}2,66 \\
6\end{array}$ & $\begin{array}{c}, 01 \\
1\end{array}$ \\
\hline \multicolumn{7}{|c|}{ a. Dependent Variable: Semangat beribadah } \\
\hline
\end{tabular}

Dari penelitian yang telah dilakukan diperoleh hasil bahwa Kegiatan Ekstrakurikuler Dakwah Rohis (X), secara simultan mempunyai pengaruh yang signifikan terhadap Semangat Beribadah Siswa dengan nilai B constant 34,640 dan 0,368 serta uji t constanta 4,649 dan 2,666 dengan taraf signifikan 0,000, dan 0,011, Pengaruh yang ditimbulkan adalah positif, yaitu semakin tinggi tingkat Kegiatan Ekstrakurikuler Dakwah Rohis (X), akan semakin tinggi pula tingkat Semangat Beribadah Siswa.

\section{Pembahasan Hasil Penelitian}

Hipotesis penelitian yang diuji adalah pengaruh yang positif dan signifikan antara variabel $\mathrm{X}$ (Kegiatan Ekstrakurikuler Dakwah Rohis) dengan variabel Y (Semangat Beribadah Siswa). Pengaruh antara variabel $\mathrm{X}$ terhadap $\mathrm{Y}$ menghasilkan nilai koefisien regresinya adalah 0,368 dengan hasil uji t mempunyai tingkat signifikansi 2,666 $(\alpha>0,05)$ (Suharsimi Arikunto, 2010). Ini menunjukkan bahwa semangat beribadah siswa dipengaruhi oleh kegiatan ekstrakurikuler dakwah rohis maka hipotesis di terima.

Berdasarkan hasil uji $\mathrm{t}$ menyebutkan bahwa dimensi Variabel $\mathrm{X}$ (Kegiatan Ekstrakurikuler Dakwah Rohis) berpengaruh signifikan dan positif terhadap Variabel Y (Semangat Beribadah Siswa) dan dapat di terima (Emzir, 2010). Dengan hasil perhitungan data menggunakan program pengolahan data SPSS versi 25.00 diperoleh hasil bahwa nilai signifikansi sebesar 0,011 dengan arah hubungan positif.

Oleh karena itu dapat di simpulkan bahwa terdapat pengaruh yang berjalan searah dan signifikan dengan sedang atau cukup antara Variabel $\mathrm{X}$ (Kegiatan Ekstrakurikuler Dakwah Rohis) terhadap Variabel Y (Semangat Beribadah Siswa), artinya tinggi rendahnya konsentrasi kegiatan ekstrakurikuler dakwah rohis dapat di pengaruhi oleh semangat beribadah siswa.

Sedangkan uji hasil koefisian determinasi $\left(\mathrm{R}^{2}\right)$ dari hasil olah data SPSS 25.00 yaitu sebesar $0,397 \quad(39,7 \%)$ maka dapat disimpulkan bahwa kegiatan ekstrakurikuler dakwah rohis bersamasama berpengaruh terhadap semangat beribadah siswa, atau model sudah tepat.

\section{KESIMPULAN}

Dengan dilakukannya analisis data, pengujian persyaratan analisis, serta pembahasan hasilnya di BAB IV, maka dapat disimpulkan bahwa: Berdasarkan hasil uji t terlihat dari hasil olah data SPSS 25.00 yaitu nilai constanta sebesar 0,368 dengan hasil uji $\mathrm{t}$ mempunyai tingkat signifikansi 2,666 $(\alpha>0,05)$ berarti secara parsial terdapat pengaruh yang signifikan dan searah antara Variabel X (Kegiatan Ekstrakurikuler Dakwah Rohis) terhadap Variabel Y (Semangat Beribadah Siswa) di SMPN 28 Tangerang.

Maksud terdapat pengaruh yang signifikan dan searah adalah semakin baik kegiatan ekstrakurikuler dakwah rohis maka semakin meningkat pula semangat beribadah yang dimiliki siswa di SMPN 28 Tangerang, jika semakin buruk kegiatan ekstrakurikuler dakwah rohis akan 
menghambat semangat beribadah siswa di SMPN 28 Tangerang.

Pengaruh kegiatan ekstrakurikuler dakwah rohis merupakan salah satu faktor yang mempengaruhi semangat beribadah siswa di SMPN 28 Tangerang, karena hasil yang didapatkan dengan kategori sedang atau cukup, berarti masih banyak faktor faktor lainnya yang mempengaruhi.

\section{DAFTAR PUSTAKA}

Prihatin, Eka, Manajemen Peserta Didik, (Bandung: Alfabeta, 2011), hal. 165. Koesmarwanti dan Widayantoro, Nugroho, Dakwah Sekolah di Era Baru, (Solo: Era Inter Media, 2000), hal. 142-151.

Nugroho Widiyantoro, Panduan Dakwah Sekolah, Kerja Besar Untuk Perubahan Besar, (Bandung: Syaamil Cipta Media, 2003), hal. 26

Hasil Olah Data Tanggal 05 Februari 2019 Menggunakan SPSS versi 25.00.
Hasil Olah Data Tanggal 05 Februari 2019 Menggunakan SPSS versi 25.00.

Adz-Dzaky, Hamdani Bakran. Konseling dan Psikoterapi Islam, (Yogyakarta:

Fajar Pustaka Baru, 2002), hal. 14

Alim, Muhammad. Pendidikan Agama Islam Upaya Pembentukan Pemikiran dan Kepribadian

Muslim, (Bandung: PT Remaja Rosdakarya, 2011), hal. 25

Arikunto, Suharsimi. Prosedur Penelitian Suatu Pendekatan Praktik, (Jakarta: Rineka Cipta, 2010), hal. 26

Emzir. Metodologi Penelitian Kualitatif: Analisis Data, (Jakarta: Rajawali Pers 2012), hal. 17

Depag. Kegiatan Ekstrakurikuler Pendidikan Agama Islam pada Sekolah Umum dan Madrasah; Panduan Untuk Guru dan Siswa, (Jakarta: Depag RI, 2004). hal $11-13$ 